\title{
The Rise of Russia-China International Cooperation in Higher Education
}

\author{
Evgeniya Katkova \\ Department of Theory and History of International Relations \\ Peoples' Friendship University of Russia \\ Moscow, Russia \\ E-mail: yeniya.dorogova@gmail.com
}

\author{
Dmitry Sidorov \\ Institute for Contemporary International Studies \\ Diplomatic Academy of Russian Foreign Ministry \\ Moscow, Russia \\ E-mail: d.a.sidorov@mail.ru
}

\author{
Ruochen $\mathrm{Wu}$ \\ Department of Theory and History of International \\ Relations \\ Peoples' Friendship University of Russia \\ Moscow, Russia
}

\begin{abstract}
The article is devoted to the scientific and educational cooperation of Russia and China and discusses the priority areas of Russian educational services' export to China which can become an effective tool of the "soft power" in Russia's foreign policy. The authors examine the history of Russian - Chinese ties in the field of higher education, the legal framework of the relations, and the current state of cooperation between the two countries at the university level.
\end{abstract}

Keywords-education; agreements; development; students exchange; universities; direct contacts

\section{INTRODUCTION}

The main task of the foreign policy of any state is to strengthen its authority and position in the international arena. The ways to solve this problem differ in different times. In the past century, countries sought to increase their military potential to achieve this goal. Today, there are changes associated with the growth of global interdependence and transformations in foreign policy processes that are primarily reflected in a shift in emphasis. Namely, the transition from using traditional power as a combination of military-political and economic power to achieve political interest in soft power is becoming more and more noticeable. In this regard, the role of international cooperation in the field of education is sharply increasing.

At the beginning of the XXI century, states seek to attract more "minds" and talented students. Foreign students are actively learning the language of the host country, its culture, traditions, history etc., then return home with new knowledge and a deep sympathy for the country in which they studied. Aftermath, they become agents of increased cooperation between their country and the country of their Alma Mater.

Russia has a wealth of experience in attracting foreign students. This tradition was founded in the Soviet times, when students from different countries of Africa, Asia and Latin America studied in Soviet universities, and after returning home have held prominent positions inpolitics and economics and remained committed to cooperation with the USSR. In turn, China today is the fastest growing country which is actively seeking to learn from the valuable experience of other countries.

Now the relations between China and Russia are experiencing an unprecedented rise. Cooperation is carried out in the political, economic, energy, military spheres, in the field of space development and especially in the humanitarian sphere. Thus, cooperation in the field of higher education occupies an important place in the RussianChinese relations of a comprehensive strategic partnership.

\section{HISTORY OF RUSSIAN-CHINESE RELATIONS IN THE FIELD OF EDUCATION}

Long before the American political scientist Joseph Nye coined the term "soft power" and experts from different countries studied the fullness of its tool base enhancing their attractiveness abroad, the Soviet Union successfully had used higher education as an instrument of achieving its foreign policy goals during the Cold war. Chinese students began studying in the USSR in the 1920s. In 1921, The Communist University of the Toilers of the East was opened in Moscow. In 1925, Sun Yat-sen Communist University of the Toilers of China (Moscow Sun Yat-sen University) was opened and operated from 1925 to 1930.In 1939, Zhou Enlai brought the children of famous Chinese revolutionaries to the USSR, where they received a secondary education and entered higher education institutions in Moscow [1]. In the second half of the 1950s, the number of foreign students in the USSR increased dramatically. On February 5, 1960, the Patrice Lumumba University of Peoples' Friendship (Peoples' Friendship University of Russia) was founded to become an educational institution for the training of 
personnel from emerging countries in Asia, Africa and Latin America. The university trained such well-known people such as: Abbas Yusuf Saleh (Prime Minister of Chad from 2008 to 2010),Bheri Sygmond Ramsaran (Guyana's Minister of Public Health from (2006 to 2011), Tamar Beruchashvili (Georgian Foreign Minister in 2014-2015), Bharrat Jagdeo (President of Guyana in 1999-2011) and many others [2].

Russian-Chinese relations in the field of education were established before the creation of the People's Republic of China and successfully developed until 1966.Since the mid1950s, Sino-Soviet relations acquired a confrontational character, which naturally affected cooperation in the educational sphere. The flow of students from the PRC was sharply reduced, and cultural exchange between the countries stopped altogether in 1966. In the 1970s, the territorial conflict between the USSR and the PRC did not allow the governments to deepen and expand bilateral contacts. However, the Soviet authorities understood the significance of the relations with their neighbor. Therefore, in 1982, during the celebration of the 60th Anniversary of the Soviet Union in Tashkent, Leonid Brezhnev took the initiative to resolve the Sino-Soviet border dispute. In his speech, he proposed to normalize the Soviet-Chinese relations. The Chinese government supported this idea. In 1985, when Mikhail Gorbachev took the post of the General Secretary of the Communist Party of the Soviet Union the Soviet-Chinese relations received a new impetus in development. As a reformer, the Soviet leader was able to convince the Chinese authorities of the need for a full-scale stabilization policy and forging contacts between our countries. In 1989, Mr Gorbachev arrived in Beijing on an official visit, and in 1990, Premier of the State Council of the People's Republic of China, Li Peng, made a return visit to Moscow. During this period, several contracts and agreements in the field of trade, economy, science, technology and education were signed.

Thus, by the late 1980s and early 1990s, there was a turning point in the bilateral Soviet-Chinese relations. The transition from an apparent confrontation to the constructive dialogue in various fields had been completed. From this time until today, countries develop the equal mutually beneficial partnership.

\section{THE LEGAL FRAMEWORK FOR RUSSIAN-CHINESE EDUCATIONAL COOPERATION}

In the 1990s, a new stage in the development of bilateral relations between China and Russia in the field of education and science began. It was then that a strong base to form the new regulatory framework was laid. The events of 1991 (the collapse of the Soviet Union and the world socialist system) affected not only the alignment of forces in the international arena, but also Russian-Chinese cooperation. Since 1991, when the People's Republic of China officially recognized the Russian Federation as the successor of the USSR, a number of important treaties were concluded at the highest level. During the first visit of the Russian President Boris Yeltsin to Beijing in the 1992, an important document - the "Agreement between the Government of the Russian Federation and the Government of the People's Republic of
China on cultural cooperation" - was signed. Article 2 of the Agreement was devoted to deepening cooperation in the field of education. The parties agreed: to exchange experience between scholars, teachers and specialists; to provide scholarships; to explore the possibility of signing an agreement on the equivalence of educational documents, academic degrees and titles; to facilitate the establishment of direct contacts between higher educational institutions; to assist the study of Chinese and Russian languages in educational institutions [3]. This agreement marked the beginning of a full-scale cooperation in the scientific and educational sphere and was a confirmation of the desire to further develop friendly relations between nations and to strengthen cultural cooperation between the two countries.

The next step in the field of educational activities was the signing of the "Agreement on Mutual Recognition and Equivalence of Documents on Education and Academic Degrees" in 1995 [4]. In April 1996, Boris Yeltsin visited China again. During the visit, the leaders signed the "Russian-Chinese Joint Declaration on a Multipolar World and the Establishment of a New International Order". It should be noted that from the very beginning this document had purely political significance, subsequently; this interaction was spreading to the cultural and humanitarian sphere. Vladimir Putin, who was elected President of Russia in 2000, made a significant contribution to the development of the bilateral contacts between Russia and China. On July 16, 2001, the countries signed the "Treaty of GoodNeighborliness and Friendly Cooperation between the People's Republic of China and the Russian Federation" giving a new status to the Russian-Chinese relations. The document gave a strong impetus for the continuation of promising cooperation in the field of education, including the need to "enhance and develop exchanges and cooperation in culture, education, health, information, tourism, sports and legal matters" [5]. In 2000, The Russian-Chinese Intergovernmental Commission for Cooperation in education, culture, health, and sports was set up. The establishment of this Commission played a significant role in expanding and deepening contacts between Russia and China in the humanitarian field. In 2007, it was renamed the Russian-Chinese Commission for humanitarian cooperation. The Russian-Chinese sub-Commission on cooperation in the field of education actively operates within it. This subCommission has been held the high-level meetings on a regular basis in Russia and China since 2000.

In 2006, the Ministry of Education and Science of the Russian Federation and Ministry of Education of the People's Republic of China sighed the Agreement on cooperation in the field of education. The parties agreed to make efforts to maintain constructive relations and establish long-term cooperation on the following main aspects:

- to provide students, scientists and professors exchanges;

- to ensure direct inter-university cooperation;

- to popularize the Chinese language in Russia and Russian language in China; 
- to carry out various activities promoting the development of interaction in the field of humanitarian, natural science and technical education;

- to promote the expansion of the information base through the creation of various networks and sites related to Russian and Chinese educational structures [6].

In June 2011, the Ministry of Education and Science of the Russian Federation adopted a five-year program " 100,000 foreign students" allowing Russia to be included in the list of countries most attractive to foreign students. China became Russia's one of the most important partners in the implementation of this program. [7].

In addition to these documents, the countries have also signed: Agreement on the study of the Russian language in China and the Chinese language in the Russia (2003), Memorandum of Understanding between the Ministry of Education and Science of the Russian Federation and the Ministry of Education of the People's Republic of China on cooperation in the implementation of priority areas in the field of education (2012), Memorandum on the implementation of the Action Plan for Russian-Chinese cooperation in the humanitarian sphere until 2020. The development of this Plan has not yet been completed, but it is already possible to identify several areas in which its implementation will be carried out:

- the implementation of direct contacts at the interuniversity level, especially in the border areas;

- the exchange of specialists and training in higher and postgraduate educational programs, the creation of postgraduate courses, and the conducting scientific internships;

- the modernization of curricula and methods for the study and teaching of Russian and Chinese as foreign languages;

- the organization of festivals and exhibitions, language competitions and contests;

- the creation of favorable conditions for the spread of Chinese culture in Russia and Russian culture in China;

- the enhancing of the research centers' potential and the encouraging of the education in a partner country with government scholarships;

- the creation of Internet sites about educational services of higher educational institutions of the two countries;

- the formation of a common bank of resources in the humanitarian sphere;

- the strengthening contacts between educational institutions.

Thereby, the Russia - China relations in the scientific and educational sphere are successfully developing. The leaders of our two countries constantly emphasize the need for further development of contacts in these areas. On June 8, 2018, in a joint statement Vladimir Putin and Xi Jinping emphasized that cooperation in practical areas makes a significant contribution to strengthening the foundation of relations between Russia and China. They noted the significant positive development in many areas of cooperation, including the implementation of large joint projects, the continuous expansion of cooperation in the field of science, technology and education etc. [8].

\section{COOPERATION BETWEEN UNIVERSITIES AND HIGHER EDUCATIONAL INSTITUTIONS}

Attracting Chinese students to Russian universities and Russian students to Chinese universities has always been a priority to the Ministries of Education of the two countries. In recent years, the process of stimulating academic mobility has become increasingly widespread. In the 1990s, the partnership began to be implemented not only on an interstate, but also on an intercollegiate level. Now, the driving factors determining the desire of Chinese students to study in Russia are the territorial proximity, the simplicity of the visa regime and the relatively low educational fees.

Peoples' Friendship University of Russia (RUDN University) has become one of the universities implementing international cooperation with China. The cooperation between RUDN University and Chinese universities began in 1993, when RUDN signed a protocol on scientific and pedagogical cooperation with the Chinese Capital Normal University, Beijing. In 1997, RUDN and People's Public Security University of China concluded a framework student exchange agreement, and in 2000-2001 first Chinese students arrived in Moscow [9]. The first Chinese university RUDN established close cooperation with was the University of Science and Technology of China (September 1990). RUDN is also developing cooperation with: Renmin University of China, Xiamen University, Minzu University of China, University of Jinan, Zhengzhou University, Henan University, Xi'an International Studies University and Beijing Foreign Studies University etc. RUDN is developing a friendship relation with Shandong University which becomes one of the University's leading Chinese partners. Cooperation with the Shandong University is characterized by regular student exchanges. In recent years, student exchange has been a priority, and about 20 students from each university come annually for internships.

One of the main Chinese partners is Lomonosov Moscow State University (MSU). MSU has concluded more than 40 contracts in the field of education with the Chinese side. Recently, the number of Russian students wishing to learn Chinese has noticeably increased. In addition to the Institute of Asian and African Studies of MSU the number of students studying Chinese has increased in many other humanitarian faculties. Another Moscow university - the Russian State University for the Humanities (RSUH) — has successfully cooperated with many educational institutions of the People's Republic of China. In 2007, on the basis of the intergovernmental agreement between Russia and China and the agreement between RSUH and the Office of Chinese 
Language Council International the Confucius Institute was established.

One of the fundamental instruments of cooperation between the two countries in the field of education are the forums for rectors of Russian and Chinese universities. For the first time such a meeting was held in 2005 in Moscow by the initiative of the MSU rector, Victor Sadovnichy, and the rector of Beijing University, Xu Zhihong. The rectors discussed the current state and development of national systems of higher professional education and the expanding direct partnerships between Russian and Chinese universities. In the 2000-2010s, there were regular forums for university rectors were held in Chinese northeastern provinces and Russian Siberia and the Far East.

Analyzing such an important form of university cooperation as the forums for rectors, it should be noted that meetings are an extremely important stage in RussianChinese cooperation in the field of education. It contributes to the strengthening and development of cooperation between higher education institutions of the two countries and the expansion of cooperation in solving problems related to the modernization of higher education.

\section{CONCLUSION}

Russia and China need qualified specialists to maintain stability and prosperity of their people. Training of competent researchers has become one of the priorities of the Russian and Chinese governments. The leaders are ready to exchange experience, expand the resource base of educational services, cooperate at the highest state level, maintain and develop contacts on an inter-University basis, at the level of public organizations and structures. Training competent specialists has become one of the priorities for the Russian and Chinese governments. Today, countries are ready to share experiences, expand the educational services' resource base, cooperate at the highest state level, maintain and develop contacts at the inter-university level.

The contractual base of Russian-Chinese modern educational cooperation continues to improve. A rather strong legal framework supports and promotes the development of a constructive dialogue between two countries. Thanks to international integration in the field of science and education, the internationalization of curricula and academic mobility, the introduction of digital technologies and institutional partnership, our countries can significantly increase their competitiveness in the international arena.

\section{REFERENCES}

[1] Verchenko, A.L. "Chinese students in the USSR in 1920-1950: fathers and children". Proceedingsof the XXIX International Congress on the Source and Historiography of Asian and African Countries "Asia and Africa: Heritage and Modernity". June 21-23, 2017. St. Petersburg: NP-Print Studio, 2017, pp. 71-73.

[2] Outstanding graduates of the Peoples' Friendship University of Russia // RUDN. URL: http://www.rudn.ru/?pagec $=2920$ (accessed: 08.10.2018).
[3] Agreement between the Government of the Russian Federation and the Government of the People's Republic of China on cultural cooperation // Russian Foreign Ministry. URL:http://www.mid.ru/foreign_policy/international_contracts/2_con tract/-/storage-viewer/bilateral/page-356/48731_ (accessed: 08.10.2018).

[4] Agreement on Mutual Recognition and Equivalence of Documents on Education and Academic Degrees // National Information Center. URL:

http://nic.gov.ru/ru/docs/foreign/confirmation/idokb_2577_225553 (accessed: 08.10.2018).

[5] Treaty of Good-Neighborliness and Friendly Cooperation Between the People's Republic of China and the Russian Federation // Ministry of Foreign Affairs, the People's Republic of China. URL: https://www.fmprc.gov.cn/mfa_eng/wjdt_665385/2649_665393/t157 71.shtml (accessed: 08.10.2018).

[6] Agreement between the Ministry of Education and Science of the Russian Federation and Ministry of Education of the People's Republic of China on cooperation in the field of education // National Information Center. URL: http://nic.gov.ru/ru/docs/foreign/collaboration/agreem_coop_China_2 006 (accessed: 08.10.2018).

[7] Liu, J. "Development of Russian-Chinese Relations in the Field of Education”. Education and Science. 2013. Vol. 109. No 10, pp. 91104.

[8] Joint Statement by the Russian Federation and the People's Republic of China, June 8, 2018 // Presidential Administration of Russia. URL: http://kremlin.ru/supplement/5312 (accessed: 08.10.2018).

[9] Kitinov, B.U., Solodkova, O.L. RUDN University and Asian countries. M.: Peoples' Friendship University of Russia, 2010. 